\title{
The Wnt connection to tumorigenesis
}

\author{
JÜRGEN BEHRENS ${ }^{*}, 1$ and BARBARA LUSTIG ${ }^{2}$ \\ ${ }^{1}$ Nikolaus-Fiebiger-Center for Molecular Medicine, University Erlangen-Nürnberg, Erlangen, Germany and ${ }^{2}$ Clinic \\ for Abdominal, Endocrine and Thoracic Surgery, Klinikum Nürnberg, Nürnberg, Germany
}

\begin{abstract}
Wnt signaling has been identified as one of the key signaling pathways in cancer, regulating cell growth, motility and differentiation. Because of its widespread activation in diverse human tumor diseases, the Wnt pathway has gained considerable and growing interest in tumor research over recent years. Evidence that altered Wnt signaling is important for human tumor development came from three major findings: (i) the tumor suppressor adenomatous polyposis coli (APC) binds to the Wnt pathway component $\beta$-catenin and is involved in its degradation, (ii) mutations of $A P C$ in colon tumors lead to stabilization of the $\beta$-catenin protein and (iii) tumorassociated mutations of $\beta$-catenin in colorectal cancer as well as in other tumor types lead to its stabilisation, qualifying $\beta$-catenin as a proto-oncogene. Here we will describe the biochemical interactions which shape the Wnt pathway and focus on its role in tumorigenesis.
\end{abstract}

KEY WORDS: wnt, tumor, $\beta$-catenin, APC, mutation

\section{Introduction}

In mammals, the first Wnt gene to be identified was called int-1 because it was activated by integration of the LTR of the mouse mammary tumor virus resulting in the development of mammary tumors in mice. In Drosophila the homologous gene of int- 1 is called wingless, and the combination of both names led to the term Wnt (Rijsewijk et al.,1987a). In the so called canonical Wnt signaling pathway the cytoplasmic protein $\beta$ catenin becomes stabilized and then associates with transcription factors of the LEF/TCF family (hereafter collectively referred to as TCF). The TCF/ $\beta$-catenin complexes regulate expression of specific target genes thereby transmitting the Wnt signal to the cell nucleus. Besides canonical signaling there are two more main branches of the Wnt pathway: the planar cell polarity pathway, which controls cytoskeletal rearrangments, involving RhoA and Jun Kinase, and the Wnt/ $\mathrm{Ca}^{2+}$ pathway, which acts via calmodulin dependent kinase, calcineurin and the transcription factor NF-AT (Veeman et al., 2003, Kuhl 2004). In the following we will focus on the canonical Wnt pathway and its implication in cancer development and progression. The possible roles of the planar cell polarity and $\mathrm{Ca}^{2+}$ pathways in tumorigenesis are less defined and will not be discussed here.

Wnt signaling has been identified and studied extensively in embryonal development. In Xenopus embryos ectopic expression of Wnts induces dorsalization of the embryos and forma- tion of a secondary body axis, resulting in double-headed embryos. This phenomenon is also observed with other activating components of the Wnt pathway while inhibitors lead to defects in axis formation. Thus, if the amount of $\beta$-catenin is increased, e.g. by injecting $\beta$-catenin mRNA a secondary bodyaxis forms, whereas if negative regulators such as axin are expressed axis formation is disturbed and ventralization of the embryos occurs. In addition to Xenopus embryology, studies in Drosophila melanogaster and Caenorhabditis elegans have been most powerful in identifying and charaterizing new components of the pathway. Mice mutated in Wnt pathway components have contributed to our understanding of the physiological role of the Wnt pathway in mammals, and more recently, zebrafish genetics has also entered the Wnt field.

\section{Molecular mechanisms of the canonical Wnt signal transduction pathway}

A combination of biochemical and developmental studies together with tumor genetics have contributed to the model of molecular interactions of the Wnt pathway that will be described here. Our model is simplified as it contains only a selection of components for which an essential role has been suggested by different functional studies (Fig. 1).

Abbreviations used in this paper: APC, adenomatous polyposis coli tumor suppressor; FAP, familial adenomatous polyposis.

\footnotetext{
*Address correspondence to: Dr. Jürgen Behrens. Nikolaus-Fiebiger-Center, Glückstrasse 6, 91054 Erlangen, Germany. Fax: ++49-9131-852-9111. e-mail: jbehrens@molmed.uni-erlangen.de
} 


\section{Signaling at the plasma membrane}

Wnts are secreted glycoproteins which are produced by different cell types and are thought to act mostly in a paracrine fashion (Cadigan and Nusse 1997). There are $19 \mathrm{Wnt}$ proteins known only some of which, such as Wnt-1, Wnt-3a and Wnt-8 activate the canonical Wnt/B-catenin pathway. Wnts bind to seven transmembrane receptors called frizzelds and to co-receptors LRP-5 and LRP-6, which are essential for signal transmission (Bhanot et al., 1996, Tamai et al., 2000, Wehrli et al., 2000, Mao et al., 2001a). The interaction of Wnts with frizzled receptors can be modulated by secreted factors, which act as direct or indirect antagonists. While WIF-1, Cerberus and FrzB bind to Wnts and thereby directly prevent its interaction with frizzleds (Miller 2002), members of the Dickkopf family (Dkk-1, DKK-2, but not DKK-3) prevent Wnt binding in an indirect fashion by reducing availability of the LRP co-receptors. Dkk was shown to promote endocytosis of LRP by interacting with the transmembrane protein Kremen (Mao et al., 2001a, Mao et al., 2002).

\section{Signaling in the cytoplasm}

The molecular events taking place immediately after activation of frizzleds remain largely elusive. It is clear from most of the genetic as well as biochemical data that the cytoplasmic phosphoprotein dishevelled plays a crucial role (Wharton 2003). After activation of Wnt signaling dishevelled becomes recruited to the plasma membrane possibly by interaction with phospholipids (Capelluto etal., 2002). It is thought that this step leads to activation of dishevelled which can then interfere with $\beta$-catenin degradation. The precise nature of the activation mechanism of dishevelled is not known although phosphorylation of dishevelled might be important. A number of dishevelled interacting proteins have been identified, such as Dapper, Frodo, Daam1, Stbm, PAR-1, and Nkd,

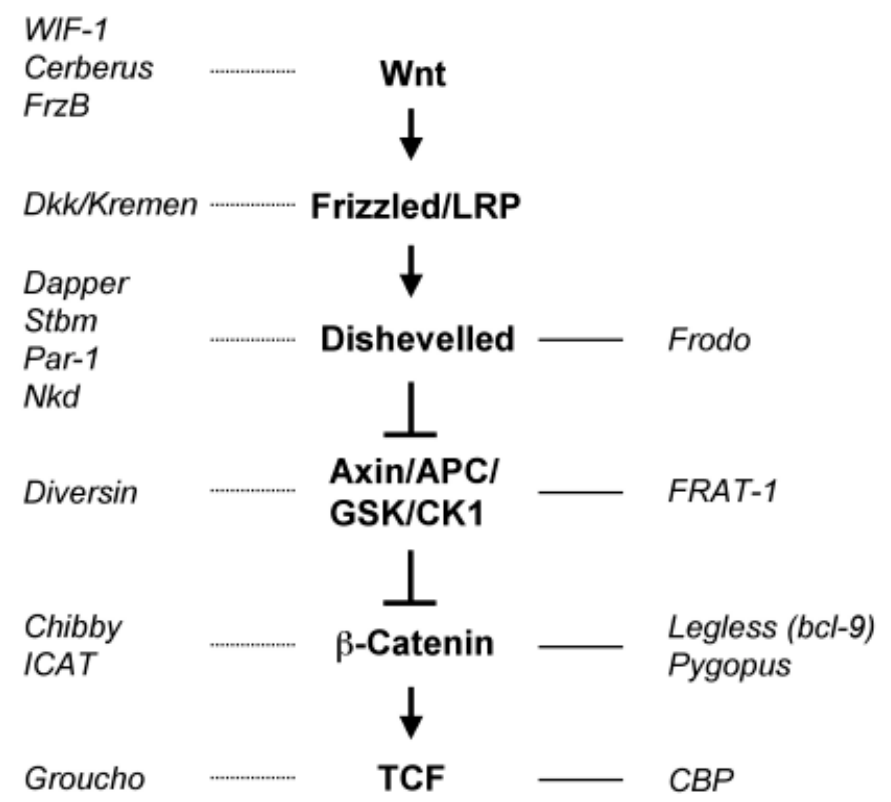

Fig. 1. Overview of the Wnt pathway. The central components of the canonical Wnt signaling cascade are shown in bold type. Factors which modulate Wnt signaling at different levels of the cascade are shown in italics. Inhibitors are depicted to the left (stippled lines) and activators to the right (straight lines). which can either activate or inhibit Wnt signaling in different experimental settings through binding to distinct domains of dishevelled (Habas et al., 2001, Rousset et al., 2001, Sun et al., 2001, Cheyette et al., 2002, Gloy et al., 2002, Heisenberg 2002). The functional role of most of these components in mammalian development or in cancer has not been analysed yet. An alternative, more direct way for cytoplasmic propagation of the Wnt signal is the binding of axin to LRP receptors, which blocks function of the $\beta$-catenin destruction complex (see below, (Mao et al., 2001b)).

The levels of cytoplasmic $\beta$-catenin are normally controlled by a multiprotein destruction complex which targets $\beta$-catenin for degradation in proteasomes (Polakis 2000, Seidensticker and Behrens 2000). This complex is assembled over the scaffold component axin or its homologue conductin, which contain binding domains for $\beta$-catenin, the tumor suppressor APC (adenomatous polyposis coli), the serine/threonine kinases GSK3 $\beta$ and casein kinase $1 \alpha / \varepsilon$ (Zeng et al., 1997, Behrens et al., 1998, Hart et al., 1998, Ikeda et al., 1998, Kishida et al., 1998, Liu et al., 2002). The main function of the destruction complex is to promote phosphorylation of $\beta$-catenin which is required to trigger ubiquitination of $\beta$ catenin and its subsequent degradation in proteasomes. The phosphorylation sites are contained in the $\mathrm{N}$-terminal domain of $\beta$ catenin and are hotspots for mutations in tumors (see below). Phosphorylation of $\beta$-catenin occurs in a two step mechanism: first, serine residue 45 is phosphorylated by the "priming kinase" casein kinase 1, and then the Ser 33, Ser 37 and Thr 41 are phosphorylated by GSK3 $\beta$ (Amit et al., 2002, Liu et al., 2002). Phosphorylated $\beta$-catenin is recognized by the ubiquitin E3 ligase $\beta-\operatorname{TrCP}$ which induces its ubiquitination (Kitagawa et al., 1999, Winston et al., 1999). The consecutive phosphorylation mechanisms implies that all four phosphorylation sites are essential for efficient degradation of $\beta$-catenin and explains why single mutations in any of these sites lead to stabilization of the $\beta$-catenin protein. While CK1 $\alpha$ can bind directly to axin, $\mathrm{CK} 1 \varepsilon$ is recruited to the degradation complex via its binding to the ankyrin repeat protein diversin which acts as a negative regulator of the Wnt signaling pathway. Diversin binds to axin or conductin at the same binding sites as does GSK3 $\beta$. However, diversin and GSK3 $\beta$ do not compete for interaction indicating that they might coexist in a common complex with axin (Schwarz-Romond et al., 2002). Axin also facilitates the phosphorylation of APC by direct binding to CK1. GSK3 $\beta$ is a multitasking protein responsible for phosphorylation of multiple Wnt signaling components including $\beta$-catenin, APC, and axin (Rubinfeld et al., 1996, Yamamoto et al., 1999). The activity of GSK3 $\beta$ can be blocked by GBP (GSK3 binding protein) in Xenopusor its orthologue Frat-1 in the mouse (Yost etal., 1998). Mutations or changes in gene expression of GSK3 $\beta$ have not been shown in tumors so far. Probably this is due to the essential role GSK3 $\beta$ in several cellular signaling which exceeds by far its role in Wnt signaling.

The phosphorylation of $\beta$-catenin by GSK3 $\beta$ is far more efficient in the presence of axin than in its absence, and overexpression of axin/conductin promotes significantly the degradation of $\beta$-catenin (Behrens et al., 1998, Ikeda et al., 1998). Thus it appears that by approximating the members of the multiprotein complex the phosphorylation of $\beta$-catenin is facilitated. Axin and conductin (also called axin2) share an overall identity in amino acids of $45 \%$ and seem to have similar biochemical functions, but they differ in their regulation. Not only do both proteins show a different expression 
pattern in embryonic development with a ubiquitous expression of axin and a very defined expression pattern of conductin, but conductin in contrast to axin is upregulated in colon, liver, and ovarian tumors (Jho et al., 2002, Leung et al., 2002, Lustig et al., 2002). The promoter of the conductin/axin2 gene contains functional TCF binding sites and biochemical experiments demonstrate that conductin is a direct target of the Wnt pathway that acts in a negative feedback mechanism.

$A P C$ has first been identified as the responsible gene mutated in familial adenomatous polyposis (FAP), an inherited disease characterized by the development of thousand of polyps in the colon, eventually leading to colon cancer (Kinzler and Vogelstein 1996). The elucidation of the role of APC as a negative regulator of $\beta$-catenin in the Wnt pathway has greatly helped in understanding its function as a tumor suppressor (Polakis 2000). The $A P C$ gene is verly large containing 21 exons that encode a 2843 amino acid protein. The central region of APC is most directly implicated in Wnt signaling. It contains three 15-amino-acids repeats and seven 20 -amino acid repeats which all bind to $\beta$-catenin. Unlike the 20 -amino-acid repeats the 15-amino acid repeats are not essential for downregulation of $\beta$-catenin and are retained in most APCtruncated tumors (Polakis 2000). Three so-called SAMP repeats containing the core sequence serine-alanine-methionine-proline interact with the RGS domain of the axin proteins (Behrens et al., 1998, Spink et al., 2000). Thus APC, like axin/conductin can be considered a scaffold protein associating with different components of the $\beta$-catenin destruction complex. In colorectal tumors mutations of the $A P C$ gene occur mostly in a mutation cluster region which is located closely $5^{\prime}$ to the sequence encoding the first SAMP repeat. These mutations generate stop codons or frameshifts leading to the deletion of the C-terminal half of the APC protein and thereby removing the interaction sites with axin/ conductin (Polakis 2000). In addition, the truncated APC also lacks several nuclear export sequences (NES) which are thought to be important for the distribution of APC between cytoplasm and the nucleus. Besides its function in regulating $\beta$-catenin degradation APC is also involved in shuttling $\beta$-catenin from the nucleus to the cytoplasm thereby interfering with its transcriptional activity. It has been speculated that this function of APC is important for its role as a tumor suppressor and that lack of $\beta$-catenin shuttling contributes to the aberrant activation of the Wnt pathway in tumors (RosinArbesfeld et al., 2003).

$\beta$-Catenin has a core domain of twelve so-called arm-repeats which were first identified in the Drosophila homologue armadillo (Peifer et al., 1994). Structurally the arm repeats are build up by three a-helices, which arrange in a superhelical fashion to generate a rod-like structure (Huber and Weis 2001). Arm repeats are also found in several other proteins including APC and have a widespread function as protein interaction domains. In $\beta$-catenin different segments of the arm domain bind to cadherins, APC, axin/ conductin, and TCFs (von Kries et al., 2000). Most of these interactions appear to be mutually exlusive, in particular the associations with cadherins and components of the destruction complex (Hulsken et al., 1994).

\section{Signaling in the nucleus}

Stabilized $\beta$-catenin enters the cell nucleus and associates with TCF/LEF transcription factors, leading to the transcription of Wnt target genes. TCFs bind to DNA via an HMG domain and to $\beta$-catenin with a short stretch of amino acids at their $\mathrm{N}$-terminus. TCFs lack transactivation function, however, in $\beta$-catenin, the $\mathrm{N}$ and in particular the $\mathrm{C}$-terminal regions that flank the arm repeat domain exhibit transcriptional activation function (Behrens et al., 1996, Huber et al., 1996, Molenaar et al., 1996, van de Wetering et al., 1997, Hsu et al., 1998).

The interaction between stabilized $\beta$-catenin and TCFs can be modulated by various direct and indirect mechanisms (Fig.1). In the absence of $\beta$-catenin, TCFs can repress gene transcription either as naturally occurring dominant-negative variants or in association with transcriptional repressors such as groucho (Roose et al., 1998). Transcriptional activity of TCF/ $\beta$-catenin complexes is increased by activators such as p300/CBP, a histone acetyl transferase, and by the chromatin-remodeling SWI/SNF complex (Hecht et al., 2000, Barker et al., 2001). A pair of factors containing DNA-induced ATPase and DNA helicase activity, pontin52 (also called TIP49) and reptin52 (TIP48) was shown to bind to $\beta$-catenin and modulate its activity in an opposite fashion, i.e. pontin52 activates while reptin52 represses activity (Bauer et al., 2000). A dominant-negative mutant of TIP49 interfered with oncogenic transformation (Feng etal., 2003). Legless/bcl-9 recruits the nuclear protein pygopus to $\beta$-catenin thereby activating the complex by a yet unknown mechanism (Kramps et al., 2002, Thompson et al., 2002). Several nuclear effectors of the TCF/ $\beta$-catenin interaction have been identified. ICAT is a small protein that binds to the central and C-terminal segments of the arm repeat domain with different parts and thereby blocks interaction of $\beta$-catenin with both TCFs and CBP (Tago et al., 2000). Similarly, the nuclear factor Chibby binds to the $\beta$-catenin arm repeats and blocks its association with TCF thereby interfering with Wnt signaling in mammalian cells and in Drosophila (Takemaru et al., 2003). Taken together the transcriptional control exerted by $\mathrm{TCF} / \beta$-catenin complexes is under stringent positive and negative regulation which might determine cell type specificities of Wnt signaling under physiological conditions and in tumor development. The various interaction partners of $\beta$-catenin in the nucleus are promising candidates to be tested for a putative role in tumorigenesis.

\section{Other tumor-related functions of Wnt pathway components}

APC has been shown recently to be associated with multiple other functions. The N-terminal part of APC harbors an oligomerization domain and a so called armadillo domain. This domain interacts with the APC-stimulated guanine nucleotide exchange factor (ASEF) thereby activating Rac (Kawasaki et al., 2000), with the kinesin superfamily protein KAP3A (Jimbo et al., 2002), and with the regulatory subunit of the phosphatase 2A (Seeling et al., 1999). The interaction of mutated but not wild-type APC with ASEF was shown to promote migration of epithelial cells, suggesting a role of ASEF in tumor invasion and metastasis (Kawasaki et al., 2003).

Recently, several components of the Wnt pathway, in particular those involved in degradation of $\beta$-catenin were shown to be associated with microtubules and the mitotic spindle apparatus. Endogenous APC was located at the distal ends of microtubules in migrating mammalian tissue-culture cells and in epithelial inner ear cells (Nathke et al., 1996, Mogensen et al., 2002). Exogenously expressed wild-type APC stabilises microtubules in vitro and in 
vivo (Zumbrunn et al., 2001). APC has also been localized to the mitotic spindle and to kinetochores, and mutation of APC in embryonic stem cells was associated with defects in chromosome segregation (Fodde et al., 2001, Kaplan et al., 2001). Thus loss of APC could lead to chromosomal instability and thereby promote cancer progression. Similar to APC, axin was detected at microtubules and shown to protect microtubules against depolymerization by nocodazole. Furthermore, dishevelled seems to cooperate with axin in the control of microtubule stability (Ciani et al., 2004). Also, both GSK3 and $\beta$-catenin were found to be associated with the mitotic spindle (Olmeda et al., 2003, Kaplan et al., 2004), and interference with $\beta$-catenin through RNAi led to disturbance of centrosome separation and formation of monoastral spindles (Kaplan et al., 2004), while inhibition of GSK activity with specific drugs led to disturbances in chromosome movements and development of astral microtubules (Wakefield et al., 2003). Taken together it appears that the members of the $\beta$-catenin destruction complex reunite at microtubules and in particular at the mitotic spindle. Whether this reflects a new functional properties of the complex connected to the Wnt pathway remains to be determined. Obviously, localization of these components at a delicate structure such as the mitotic spindle might have functional consequences for cancer development.

$\beta$-Catenin is also involved in the control of cell-cell adhesion by binding to cadherin cell adhesion molecules. It is not yet clear as to which degree the cell adhesion function of $\beta$-catenin plays a role in Wnt signaling, but it is well established from many studies that disturbances of cell junctions is a prerequisite for tumor invasion and metastasis (Behrens 1999, Christofori 2003).

\section{Wnt target genes and cancer development}

Meanwhile a large list of Wnt target genes has been compiled by investigations in model organisms and cellular systems (see http://www.stanford.edu/ rnusse/wntwindow.html for an updated list). Wnt targets include genes regulating cell proliferation and developmental processes as well as tumor progression (Fig. 2). Here we will highlight only some of those targets for which a role in tumorigenesis was shown, or can be assumed from their known function. The promoters of the $c-m y c$ and $c y c l i n D 1$ genes contain TCF binding sites and are controlled by TCF/ $\beta$-catenin complexes (He et al., 1998, Shtutman et al., 1999, Tetsu and McCormick 1999). Through both targets Wnt signaling may promote progression of cells through the cell cycle. While upregulation of c-myc leads to repression of the cyclin-dependent kinase (CDK) inhibitor $\mathrm{p} 21^{\mathrm{CIP}}$ and thus stimulates G1/S progression (van de Wetering et al., 2002), cyclin D1 can directly activate G1 phase CDKs. Obviously, regulation of cell cycle by Wnt might play a role not only in tumorigenesis but also during normal tissue regeneration and stem cell proliferation as seen in the gut (Fig. 2). Another way by which Wnt signaling could lead to accumulation of transformed cells is inhibition of apoptosis. Expression of the anti-apoptotic gene survivin was downregulated by APC and analysis of its promoter revealed TCF-4 binding sites (Zhang et al., 2001a, Kim et al., 2003). Survivin is mainly expressed at the base of the crypts of normal colon epithelium and upregulated in colon tumors, again reflecting similar roles for Wnt signalling in the normal epithelium and tumors (Fig. 2). Wnt signaling also interferes with apoptosis induced by chemotherapeutic drugs, such as vinblastine and vincristine in Rat-1 fibroblasts, and inhibition of TCF/ $\beta$-catenin increased the sensitivity of colorectal tumor cells to these compounds (Chen et al., 2001).

Wnt signaling might also affect cell proliferation by induction of expression of growth factors and their receptors. For instance, FGF18 was found to be upregulated in colorectal cancer and its promoter shown to be activated by TCF/ $\beta$-catenin (Shimokawa et al., 2003). The tyrosine kinase c-met is upregulated in polyps of FAP patients and could be down-regulated experimentally by dominant-negative TCF in colorectal tumor cells (Boon et al., 2002). c-Met is the receptor for the mesenchyme-derived Scatter Factor/HGF which is an epithelial growth factor but also promotes cell motility and invasion. Thus, upregulation of c-met could allow a cross-talk of tumor cells with the surrounding stroma and thereby promote cell proliferation and tumor cell invasion. A similar crosstalk, albeit in the opposite direction, might be generated by the upregulation of VEGF in colorectal tumor cells by TCFs, which could lead to stimulation of tumor-induced angiogenesis in the stroma and thus provide the basis for tumor growth and metastasis (Zhang et al., 2001b). These examples show that aberrant Wnt signaling is not only important for the initial expansion of the transformed cell compartment as implied by the loss of the "gatekeeper" function of APC, but might also be related to the acquisition of properties required for tumor progression. In this respect it is of significance that several proteases capable of degrading extracellular matrix such as matrilysin/MMP7and MMP-26 were identified as Wnt targets (Brabletz et al., 1999, Crawford et al., 1999, Marchenko et al., 2002). The matrix metalloproteinase matrilysin has an impact on cancer progression since deficiency of matrilysin in the APC-deficient minmice resulted in a decrease of total tumor number and size (Crawford et al., 1999). Interestingly a strong nuclear accumulation of $\beta$-catenin occurs at the invasive front of colorectal carcinomas (Fig. 2). Moreover nuclear accumulation of $\beta$-catenin together with MMP-7 expression at the invasion front was related to unfavourable outcome in colon cancer (Ougolkov et al., 2002).

The motility of tumor cells and their capacity to metastasize might also be stimulated by the Wnt-induced expression of cell adhesion and extracellular matrix proteins. For instance, CD 44, a protein implicated in metastasis formation through interaction with proteoglycans was shown to be strongly overexpressed already in aberrant crypt foci, and its expression was lost in TCF-4 knockout mice (Wielenga et al., 1999). Similarly, Nr-CAM a member of the lg superfamily of adhesion receptors was shown to be induced by either $\beta-$, or $\gamma$-catenin (plakoglobin) in colon and melanoma cell lines. Nr-CAM can transform fibroblasts and increase their motility. Finally, the $\gamma 2$ chain of laminin is also upregulated in the invasive areas of colon cancer and its gene promoter contains functional TCF binding sites (Hlubek et al., 2001).

TCFs control cell differentiation in the gut as revealed by the finding that EphB2 and EphB3 receptors were downregulated by dominant-negative TCF while their ligand ephrinB1 was upregulated. Further analysis in EphBknock-out mice showed that this differential regulation served to prevent the intermingling of cells within the intestinal epithelium (Batlle et al., 2002). This role in sorting out of cells could be of relevance for the development of intestinal adenomas as seen in the min mouse because mutant APC cells invaginate around the crypt-villus junction and avoid migration into the area of high ephrinB expression at the top of the crypt. Whether 
this is also important for human colon tumor formation remains to be determined.

The Wnt pathway, similar to other signal transduction cascades, includes mechanisms for negative feedback control. The scaffold component of the $\beta$-catenin destruction complex, conductin/axin2 is a direct target gene of Wnt signaling and might be induced to attenuate the Wnt signal in normal embryonic development (Jho et al., 2002, Leung et al., 2002, Lustig et al., 2002). Conductin is massively over-expressed in early colorectal adenomas and in carcinomas as well as in other tumors. Whether this upregulation has a functional role in the tumors in which $\beta$-catenin degradation is apparently prevented by mutations of APC or $\beta$-catenin remains to be determined. Negative control of the pathway is also achieved through the induction of dominant-negative forms of TCF-1 (Roose et al., 1999).

In the future, more candidate Wnt target genes will be deciphered from gene expression profiling studies of cellular systems and from comparisons of tumors with normal tissues. An example of such an analysis is given by Schwartz et al., who could identify Wnt targets by microarray analysis of ovarian endometrioid adenocarcinomas (Schwartz et al., 2003). Since direct targets are likely to be of particular functional significance, detailed analysis of their promoter sequences for functional interaction with TCFs by reporter assays, chromatin IP, and footprinting methods will be one criterion to sort out "key players" from "bystanders" in such studies.

\section{Effects of Wnt signaling on transformation in cell culture}

Cell culture experiments have proven useful in establishing the biochemistry of the pathway as well as determining the contribution of individual components for oncogenic transformation. Given the potential to interfere with aberrant Wnt signaling for therapeutic purposes the establishment of Wnt-dependent cellular transformation systems is also of importance for drug screening purposes.
Since the discovery of int-1 as a protooncogene a number of cell biological studies have shown that Wnts can induce transformation in vitro depending on the cell culture system and target cells. For instance, transfection of int-1 in cuboidal RAC mammary cell line resulted in morphological transformation and tumorigenicity (Rijsewijk et al., 1987b). Following the discovery of the other Wnt family members differences in their capacity to induce transformation were revealed which could be related to the activity in inducing stabilisation of $\beta$-catenin (Shimizu et al., 1997). Transformation was also achieved by directly activating the Wnt signal in the nucleus. For instance, fusion of LEF- 1 to $\beta$-catenin or to transcriptional activation domains from other transcription factors was sufficient to transform chicken embryo fibroblasts (Aoki et al., 1999). Expression of the dominant-active version of $\beta$-catenin mutated in the GSK phosphorylation sites led to anchorageindependent growth and suppression of anoikis (apoptosis after loss of cell-substrate adhesion) in MDCK cells (Orford et al., 1999), although it should be noted that in a similar experimental setting expression of $\beta$-catenin in an inducible system did not lead to anchorage-independent growth of MDCK cells (Barth et al., 1999). $\beta-$ Catenin was unable to transform 3T3 cells, while it was a potent oncogene for the RK3E epithelial cell line, indicating cell type specificity (Kolligs et al., 1999). In addition, while exogenous expression of Wnts was able to transform Rat-1 fibroblasts, expression of activated $\beta$-catenin was not sufficient, possibly because Wnts have additional activities required for transformation in these cells (Young et al., 1998). Collectively these results suggest that the oncogenic capacity of the Wnt pathway in vitrodepends on the target cell as well as the read out used to determine transformation.

Several studies have shown that interference with $T C F / \beta$ catenin signaling leads to inhibition of cell proliferation in tumor cells, in particular in colorectal cancer cell lines. For example, the expression of E-cadherin was sufficient to arrest cell growth,

Target genes

Fig. 2. Role of Wnt signaling in normal homeostasis of the colonic epithelium and in cancer. A scheme of a colon crypt with an adjacent invasive tumor is shown. The left part schematically depicts the normal sequence of epithelial proliferation, migration and apoptosis which occurs from the bottom to the top of the crypt. A gradient of physiological Wnt signalling, presumably originating from secreted Wnt factors of the surrounding stroma, is indicated. The right part shows development of a colon tumor by aberrant Wnt signaling i.e. after mutations in either APC or $\beta$-catenin. A selection of Wnt target genes with their presumed role in proliferation, cell survival and invasion is shown (see text for details). Shaded nuclei indicate increasing levels of nuclear $\beta$-catenin in the normal crypt epithelium (probably reflecting the stem cell compartment), in the central tumor areas and at the invasive front (cf. Brabletz et al., 2002).

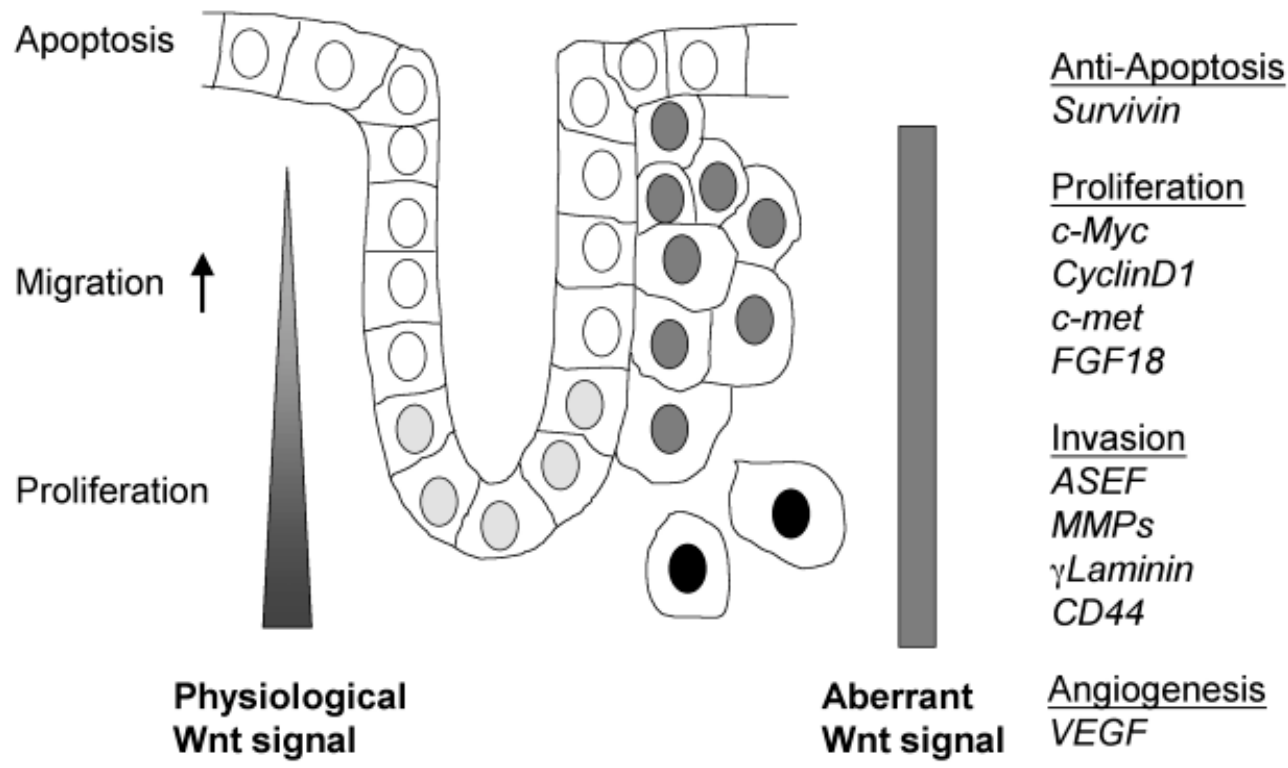

Normal epithelium
Tumor 
apparently by interfering with $\beta$-catenin signaling (Stockinger et al., 2001). Expression of a dominant-negative mutant of TCF, or knock-down of $\beta$-catenin by antisense or RNAi strategies blocks colon cancer cells in $\mathrm{G} 1$, providing proof of principle that interference with aberrant Wnt signaling could be of therapeutical value (van de Wetering et al., 2003). Recently, low molecular weight compounds were found in high throughput screens that interfere with TCT/ $\beta$-catenin complex formation and activation of target gene transcription. In addition these compounds blocked proliferation of colorectal cancer cell lines (Lepourcelet et al., 2004).

\section{Mutations of Wnt signaling components in tumors}

As mentioned above the initial clue for a role of Wnt signaling in cancer came from the discovery of the Wnt-1 (int-1) gene being transcriptionally activated in mouse mammary tumors. Whether upregulation of Wnts in human cancer plays a functional role is not known, although there are occasional reports that Wnts were found to be expressed in certain tumors. The essential finding that led to the addition of the Wnt pathway to the list of cancer relevant signaling pathways was the discovery of mutations of $A P C$ or $\beta$ catenin in colorectal cancer and later in other tumor types. Mutations of $A P C$ occur in a high proportion of colorectal carcinomas, while $\beta$-cateninis mutated in a small percentage of colorectal carcinomas and to a higher ratio in a variety of other tumors. Mutations in the $A P C$ gene are nonsense or frame shift mutations leading to a truncated APC protein. About $60 \%$ of these mutations are clustered in a 700 bp "mutation cluster region" corresponding to the $\beta$-catenin/axin binding domain. Hypermethylation of the wild-type $A P C$ allele are also found in some sporadic CRC and may constitute an alternative mechanism for $A P C$ inactivation (Hiltunen et al., 1997, Esteller et al., 2000). Most of the $\beta$-catenin mutations are activating mutations, mainly occurring in exon 3 at one of the 4 phosphorylation sites (Polakis 2000).

In most cases $A P C$ and $\beta$-catenin mutations are linked to an increase of transcriptionally active $\beta$-catenin and are mutually exclusive, reflecting their role in a common pathway (Korinek et al., 1997, Morin et al., 1997). For instance colon tumors with mutations in $A P C$ have a wild-type $\beta$-catenin gene, and vice versa, tumors with mutations in $\beta$-catenin are wild-type for $A P C$. In the following we will briefly summarize some of the mutational analyses that have been performed so far in tumors from different tissues. We will concentrate on frequent tumor diseases in which a high proportion of samples show evidence of Wnt pathway activation (for more detailed reviews see (Giles etal., 2003, Lustig and Behrens 2003))

Mutations of $A P C$ were first identified in the germline of FAP (familial adenomatous polyposis) patients. These patients develop hundreds of polyps in the colon after loss of the remaining wild-type allele demonstrating that $A P C$ behaves as a classical tumor suppressor and follows the Knudsen two-hit hypothesis. There are different phenotypes and thus subclasses of FAP associated tumors which correlate with the position of the mutations within the $A P C$ gene (for details on the genetics of APC see the article by Fodde in this issue). Since $A P C$ mutations are detected very early in the adenoma-carcinoma sequence, the APC protein has been suggested to act as a gatekeeper of colorectal carcinogenesis, which means that functional loss of APC is a prerequisite for the further progression towards malig- nancy (Kinzler and Vogelstein 1996). Importantly, about $80 \%$ of the non-inherited, sporadic CRC carry mutations of $A P C$.

Colorectal adenomas have been the first tumors in which nuclear localization of $\beta$-catenin was demonstrated (Inomata et al., 1996). Interestingly, the nuclear staining for $\beta$-catenin often shows a heterogenous pattern with strong nuclear enrichment at the invasion front and mainly cytoplasmic and membrane staining in the central tumor area. This indicates that high levels of nuclear $\beta$-catenin play a role in the transition to the invasive state of tumor cells. The molecular basis for this differential distribution of $\beta-$ catenin is not known. Obviously, one possibilty is that signals coming from the mesenchyme that surround the invasive tumor cells might lead to additional stabilisation and nuclear enrichment of $\beta$-catenin (Brabletz et al., 2002).

Mutations of $\beta$-catenin have been mainly detected in microsatellite instabile colorectal tumors (Kitaeva et al., 1997, Sparks et al., 1998). These tumors are characterized by either sporadic or, as in the case of HNPCC patients, inherited mutations in DNA mismatch repair components. It appears that mutations in $A P C$ occur less frequently in these tumors than in mismatch repair proficient cases although numbers vary between different studies (Miyaki et al., 1999, Domingo et al., 2004). Mismatch repair-deficient CRC also show heterozygous mutations in the axin2gene which resulted in truncated protein with a dominant-negative action (Liu et al., 2000, Domingo et al., 2004). However, mutations in error-prone nucleotide repeats are frequent in mismatch repair deficient tumors and may not always be of functional relevance. For instance, mutations in the TCF-4 gene found in microsatellite-instabile tumors had no effect on transcriptional activity, suggesting that they are not relevant for tumor formation (Ruckert et al., 2002).

A plethora of studies of the recent years have shown that aberrant Wnt signaling is not restricted to colorectal tumorigenesis but might play a role in a variety of other tumor types of gastrointestinal origin. Liver tumors seem to be particularly prone to harbor mutations in the $\beta$-catenin gene. Up to $70 \%$ of hepatoblastomas, which are early childhood liver tumors, and about $25 \%$ of hepatocellular carcinomas contain activated $\beta-$ catenin (de La Coste et al., 1998, Koch et al., 1999, Park et al., 2001, Taniguchi et al., 2002). In addition, mutations in the axin and axin2 genes resulting in truncated proteins were also found although at a lower frequency (Satoh et al., 2000, Taniguchi et al., 2002). APC mutations are present in $76 \%$ of sporadic gastric adenomas (Groves et al., 2002, Lee et al., 2002), while gastric carcinomas showed only few APC mutations (Lee et al., 2002). Gastric adenomas also occur in FAP patients (Groves et al., 2002). Activating $\beta$-catenin mutations were found in about one third of gastric tumor samples (Park et al., 1999, Clements et al., 2002).

In endometrial carcinomas $\beta$-catenin mutations were found in about $40 \%$ of cases and were associated with the endometrioid phenotype (Mirabelli-Primdahl et al., 1999, Moreno-Bueno et al., 2002). In ovarian carcinomas $\beta$-catenin mutations were found in 7 of 11 cases (Gamallo et al., 1999). In another study 14 of 45 ovarian endometrioid carcinomas carried mutations in $\beta$-catenin. Mutations in $A P C$, axin, and axin2 were also found in a few cases (Wu et al., 2001).

Prostate cancer has been shown to carry mutations in $\beta$ catenin, $A P C$, and the E3 Ubiquitin ligase of $\beta$-catenin, $\beta$ TrCPin 
total in about $30 \%$ of cases (Voeller et al., 1998, Chesire et al., 2000 , Gerstein et al., 2002). Functional interaction of $\beta$-catenin with the androgen receptor was also shown indicating a cross-talk of both pathways in the development of prostate cancer (Chesire et al., 2000, Truica et al., 2000, Mulholland et al., 2002, Yang et al., 2002). In transgenic animal models stabilized $\beta$-catenin induced lesions reminiscent of prostatic intraepithelial neoplasia (Gounari et al., 2002).

In sporadic anaplastic thyroid carcinomas immunofluorescence staining showed nuclear localization of $\beta$-catenin in $42 \%$ and mutations in $61 \%$ of the analyzed samples. In a further study exon 3 mutations and nuclear $\beta$-catenin localization were restricted to poorly differentiated (25\%) or undifferentiated $(66 \%)$ carcinomas (Garcia-Rostan et al., 1999, Garcia-Rostan et al., 2001). Wilms tumor as one of the most common childhood renal malignancy, has been shown to harbor $\beta$-catenin mutations with a preference for mutation of $\beta$-catenin at codon 45 , which occurred in more than $90 \%$ of the cases (Koesters et al., 1999, Maiti et al., 2000, Kusafuka et al., 2002).

In melanomas immunohistochemistry showed increased $\beta$ catenin levels, however, mutations in $\beta$-catenin were rarely detected, indicating that other components of the pathway might be affected (Rimm et al., 1999). The Microphtalmia associated trancription factor (MITF), a factor that is involved in melanocyte differentiation is a direct target of $T C F / \beta$-catenin complexes and can rescue suppression of melanoma growth by dominant-negative TCF (Widlund et al., 2002).

There is evidence that the Wnt pathway plays a role in several tumors of mesenchymal origin. $\beta$-Catenin mutations associated with nuclear localization of $\beta$-catenin are found in desmoid tumors, which represent an infiltrative form of fibromatosis; these tumors also occur in a subgroup of FAP partients. Furthermore, transgenic expression of $\beta$-catenin in mice led to development of aggressive fibromatosis (Cheon et al., 2002). Analysis of osteosarcomas revealed a cytoplasmic/nuclear accumulation of $\beta$ catenin in 33 cases out of 47 samples, but $\beta$-catenin mutations were not detected (Haydon et al., 2002).

Finally, various mutations of Wnt pathway components including $A P C, \beta$-catenin, and axin have been found in medulloblastomas (Zurawel et al., 1998, Huang et al., 2000, Dahmen et al., 2001, Koch et al., 2001, Baeza et al., 2003).

\section{References}

AMIT, S., HATZUBAI, A., BIRMAN, Y., ANDERSEN, J.S., BEN-SHUSHAN, E., MANN, M., BEN-NERIAH, Y. and ALKALAY, I. (2002). Axin-mediated CKI phosphorylation of beta-catenin at Ser 45: a molecular switch for the Wnt pathway. Genes Dev 16: 1066-1076.

AOKI, M., HECHT, A., KRUSE, U., KEMLER, R. and VOGT, P.K. (1999). Nuclear endpoint of Wnt signaling: neoplastic transformation induced by transactivating lymphoid-enhancing factor 1. Proc Nat/ Acad Sci USA 96: 139-144.

BAEZA, N., MASUOKA, J., KLEIHUES, P. and OHGAKI, H. (2003). AXIN1 mutations but not deletions in cerebellar medulloblastomas. Oncogene22: 632-636.

BARKER, N., HURLSTONE, A., MUSISI, H., MILES, A., BIENZ, M. and CLEVERS, $H$. (2001). The chromatin remodelling factor Brg-1 interacts with beta-catenin to promote target gene activation. EMBO J20: 4935-4943.

BARTH, A.I., STEWART, D.B. and NELSON, W.J. (1999). T cell factor-activated transcription is not sufficient to induce anchorage-independent growth of epithelial cells expressing mutant beta-catenin. Proc Natl Acad Sci USA 96: 4947-4952.
BATLLE, E., HENDERSON, J.T., BEGHTEL, H., VAN DEN BORN, M.M., SANCHO, E., HULS, G., MEELDIJK, J., ROBERTSON, J., VAN DE WETERING, M. PAWSON, T. and CLEVERS, H. (2002). Beta-catenin and TCF mediate cell positioning in the intestinal epithelium by controlling the expression of EphB/ ephrinB. Cel/111: 251-263.

BAUER, A., CHAUVET, S., HUBER, O., USSEgliO, F., ROTHBACHER, U., ARAGNOL, D., KEMLER, R. and PRADEL, J. (2000). Pontin52 and reptin52 function as antagonistic regulators of beta-catenin signalling activity. $E M B O J$ 19: $6121-6130$.

BEHRENS, J. (1999). Cadherins and catenins: role in signal transduction and tumor progression. Cancer Metastasis Rev18: 15-30.

BEHRENS, J., JERCHOW, B.A., WURTELE, M., GRIMM, J., ASBRAND, C. WIRTZ, R., KUHL, M., WEDLICH, D. and BIRCHMEIER, W. (1998). Functional interaction of an axin homolog, conductin, with beta-catenin, APC, and GSK3beta. Science 280: 596-599.

BEHRENS, J., VON KRIES, J.P., KUHL, M., BRUHN, L., WEDLICH, D., GROSSCHEDL, R. and BIRCHMEIER, W. (1996). Functional interaction of beta-catenin with the transcription factor LEF-1. Nature 382: 638-642.

BHANOT, P., BRINK, M., SAMOS, C.H., HSIEH, J.C., WANG, Y., MACKE, J.P., ANDREW, D., NATHANS, J. and NUSSE, R. (1996). A new member of the frizzled family from Drosophila functions as a Wingless receptor. Nature 382 : 225-230.

BOON, E.M., VAN DER NEUT, R., VAN DE WETERING, M., CLEVERS, H. and PALS, S.T. (2002). Wnt signaling regulates expression of the receptor tyrosine kinase met in colorectal cancer. Cancer Res 62: 5126-5128.

BRABLETZ, T., JUNG, A., DAG, S., HLUBEK, F. and KIRCHNER, T. (1999). betacatenin regulates the expression of the matrix metalloproteinase-7 in human colorectal cancer. Am J Patho/155: 1033-1038.

BRABLETZ, T., JUNG, A. and KIRCHNER, T. (2002). Beta-catenin and the morphogenesis of colorectal cancer. Virchows Arch 441: 1-11.

CADIGAN, K.M. and NUSSE, R. (1997). Wnt signaling: a common theme in animal development. Genes Dev 11: 3286-3305.

CAPELlUTO, D.G., KUTATELADZE, T.G., HABAS, R., FINKIELSTEIN, C.V., HE, $X$. and OVERDUIN, M. (2002). The DIX domain targets dishevelled to actin stress fibres and vesicular membranes. Nature 419: 726-729.

CHEN, S., GUTTRIDGE, D.C., YOU, Z., ZHANG, Z., FRIBLEY, A., MAYO, M.W., KITAJEWSKI, J. and WANG, C.Y. (2001). Wnt-1 signaling inhibits apoptosis by activating beta-catenin/T cell factor-mediated transcription. J Cel/ Bio/152: 8796.

CHEON, S.S., CHEAH, A.Y., TURLEY, S., NADESAN, P., POON, R., CLEVERS, H. and ALMAN, B.A. (2002). beta-Catenin stabilization dysregulates mesenchymal cell proliferation, motility, and invasiveness and causes aggressive fibromatosis and hyperplastic cutaneous wounds. Proc Natl Acad Sci USA 99: 6973-6978.

CHESIRE, D.R., EWING, C.M., SAUVAGEOT, J., BOVA, G.S. and ISAACS, W.B. (2000). Detection and analysis of beta-catenin mutations in prostate cancer. Prostate 45: 323-334.

CHEYETTE, B.N., WAXMAN, J.S., MILLER, J.R., TAKEMARU, K., SHELDAHL, L.C., KHLEBTSOVA, N., FOX, E.P., EARNEST, T. and MOON, R.T. (2002). Dapper, a Dishevelled-associated antagonist of beta-catenin and JNK signaling, is required for notochord formation. Dev Ce//2: 449-461.

CHRISTOFORI, G. (2003). Changing neighbours, changing behaviour: cell adhesion molecule-mediated signalling during tumour progression. EMBO J 22: 2318-2323.

CIANI, L., KRYLOVA, O., SMALLEY, M.J., DALE, T.C. and SALINAS, P.C. (2004). A divergent canonical WNT-signaling pathway regulates microtubule dynamics: Dishevelled signals locally to stabilize microtubules. J Cel/ Bio/164: 243-253.

CLEMENTS, W.M., WANG, J., SARNAIK, A., KIM, O.J., MACDONALD, J., FENOGLIO-PREISER, C., GRODEN, J. and LOWY, A.M. (2002). beta-Catenin mutation is a frequent cause of Wnt pathway activation in gastric cancer. Cancer Res 62: 3503-3506.

CRAWFORD, H.C., FINGLETON, B.M., RUDOLPH-OWEN, L.A., GOSS, K.J., RUBINFELD, B., POLAKIS, P. and MATRISIAN, L.M. (1999). The metalloproteinase matrilysin is a target of beta-catenin transactivation in intestinal tumors. Oncogene 18: 2883-2891. 
DAHMEN, R.P., KOCH, A., DENKHAUS, D., TONN, J.C., SORENSEN, N., BERTHOLD, F., BEHRENS, J., BIRCHMEIER, W., WIESTLER, O.D. and PIETSCH, T. (2001). Deletions of AXIN1, a component of the WNT/wingless pathway, in sporadic medulloblastomas. Cancer Res 61: 7039-7043.

DE LA COSTE, A., ROMAGNOLO, B., BILLUART, P., RENARD, C.A., BUENDIA, M.A., SOUBRANE, O., FABRE, M., CHELLY, J., BELDJORD, C., KAHN, A. and PERRET, C. (1998). Somatic mutations of the beta-catenin gene are frequent in mouse and human hepatocellular carcinomas. Proc Nat/ Acad Sci USA 95: 8847-8851.

DOMINGO, E., ESPIN, E., ARMENGOL, M., OLIVEIRA, C., PINTO, M., DUVAL, A., BRENNETOT, C., SERUCA, R., HAMELIN, R., YAMAMOTO, H. and SCHWARTZ, S., JR. (2004). Activated BRAF targets proximal colon tumors with mismatch repair deficiency and MLH1 inactivation. Genes Chromosomes Cancer 39: 138-142.

ESTELLER, M., SPARKS, A., TOYOTA, M., SANCHEZ-CESPEDES, M., CAPELLA, G., PEINADO, M.A., GONZALEZ, S., TARAFA, G., SIDRANSKY, D., MELTZER, S.J., BAYLIN, S.B. and HERMAN, J.G. (2000). Analysis of adenomatous polyposis coli promoter hypermethylation in human cancer. Cancer Res 60: 4366-4371.

FENG, Y., LEE, N. and FEARON, E.R. (2003). TIP49 regulates beta-cateninmediated neoplastic transformation and T-cell factor target gene induction via effects on chromatin remodeling. Cancer Res 63: 8726-8734.

FODDE, R., KUIPERS, J., ROSENBERG, C., SMITS, R., KIELMAN, M., GASPAR, C., VAN ES, J.H., BREUKEL, C., WIEGANT, J., GILES, R.H. and CLEVERS, H. (2001). Mutations in the APC tumour suppressor gene cause chromosomal instability. Nat Cel/ Bio/3: 433-438.

GAMALLO, C., PALACIOS, J., MORENO, G., CALVO DE MORA, J., SUAREZ, A. and ARMAS, A. (1999). beta-catenin expression pattern in stage I and II ovarian carcinomas: relationship with beta-catenin gene mutations, clinicopathological features, and clinical outcome. Am J Patho/155: 527-536.

GARCIA-ROSTAN, G., CAMP, R.L., HERRERO, A., CARCANGIU, M.L., RIMM, D.L. and TALLINI, G. (2001). Beta-catenin dysregulation in thyroid neoplasms: down-regulation, aberrant nuclear expression, and CTNNB1 exon 3 mutations are markers for aggressive tumor phenotypes and poor prognosis. Am J Pathol 158: 987-996.

GARCIA-ROSTAN, G., TALLINI, G., HERRERO, A., D'AQUILA, T.G., CARCANGIU, M.L. and RIMM, D.L. (1999). Frequent mutation and nuclear localization of betacatenin in anaplastic thyroid carcinoma. Cancer Res 59: 1811-1815.

GERSTEIN, A.V., ALMEIDA, T.A., ZHAO, G., CHESS, E., SHIH IE, M., BUHLER, K., PIENTA, K., RUBIN, M.A., VESSELLA, R. and PAPADOPOULOS, N. (2002). APC/CTNNB1 (beta-catenin) pathway alterations in human prostate cancers. Genes Chromosomes Cancer 34: 9-16.

GILES, R.H., VAN ES, J.H. and CLEVERS, H. (2003). Caught up in a Wnt storm: Wnt signaling in cancer. Biochim Biophys Acta 1653: 1-24.

GLOY, J., HIKASA, H. and SOKOL, S.Y. (2002). Frodo interacts with Dishevelled to transduce Wnt signals. Nat Cel/ Bio/4: 351-357.

GOUNARI, F., SIGNORETTI, S., BRONSON, R., KLEIN, L., SELLERS, W.R., KUM, J., SIERMANN, A., TAKETO, M.M., VON BOEHMER, H. and KHAZAIE, K. (2002). Stabilization of beta-catenin induces lesions reminiscent of prostatic intraepithelial neoplasia, but terminal squamous transdifferentiation of other secretory epithelia. Oncogene 21: 4099-4107.

GROVES, C., LAMLUM, H., CRABTREE, M., WILLIAMSON, J., TAYLOR, C., BASS, S., CUTHBERT-HEAVENS, D., HODGSON, S., PHILLIPS, R. and TOMLINSON, I. (2002). Mutation cluster region, association between germline and somatic mutations and genotype-phenotype correlation in upper gastrointestinal familial adenomatous polyposis. Am J Patho/160: 2055-2061.

HABAS, R., KATO, Y. and HE, X. (2001). Wnt/Frizzled activation of Rho regulates vertebrate gastrulation and requires a novel Formin homology protein Daam1. Cel/107: 843-854.

HART, M.J., DE LOS SANTOS, R., ALBERT, I.N., RUBINFELD, B. and POLAKIS, P. (1998). Downregulation of beta-catenin by human Axin and its association with the APC tumor suppressor, beta-catenin and GSK3 beta. Curr Bio/8: 573-581.

HAYDON, R.C., DEYRUP, A., ISHIKAWA, A., HECK, R., JIANG, W., ZHOU, L., FENG, T., KING, D., CHENG, H., BREYER, B., PEABODY, T., SIMON, M.A., MONTAG, A.G. and HE, T.C. (2002). Cytoplasmic and/or nuclear accumulation of the beta-catenin protein is a frequent event in human osteosarcoma. Int $\mathrm{J}$ Cancer 102: 338-342.
HE, T.C., SPARKS, A.B., RAGO, C., HERMEKING, H., ZAWEL, L., DA COSTA, L.T., MORIN, P.J., VOGELSTEIN, B. and KINZLER, K.W. (1998). Identification of C-MYC as a target of the APC pathway. Science 281: 1509-1512.

HECHT, A., VLEMINCKX, K., STEMMLER, M.P., VAN ROY, F. and KEMLER, R. (2000). The p300/CBP acetyltransferases function as transcriptional coactivators of beta-catenin in vertebrates. EMBO J19: 1839-1850.

HEISENBERG, C.P. (2002). Wnt signalling: refocusing on Strabismus. Curr Bio/12: R657-659.

HILTUNEN, M.O., ALHONEN, L., KOISTINAHO, J., MYOHANEN, S., PAAKKONEN, M., MARIN, S., KOSMA, V.M. and JANNE, J. (1997). Hypermethylation of the APC (adenomatous polyposis coli) gene promoter region in human colorectal carcinoma. Int J Cancer 70: 644-648.

HLUBEK, F., JUNG, A., KOTZOR, N., KIRCHNER, T. and BRABLETZ, T. (2001). Expression of the invasion factor laminin gamma2 in colorectal carcinomas is regulated by beta-catenin. Cancer Res 61: 8089-8093.

HSU, S.C., GALCERAN, J. and GROSSCHEDL, R. (1998). Modulation of transcriptional regulation by LEF-1 in response to Wnt-1 signaling and association with beta-catenin. Mol Cel/ Biol18: 4807-4818.

HUANG, H., MAHLER-ARAUJO, B.M., SANKILA, A., CHIMELLI, L., YONEKAWA, Y., KLEIHUES, P. and OHGAKI, H. (2000). APC mutations in sporadic medulloblastomas. Am J Patho/156: 433-437.

HUBER, A.H. and WEIS, W.I. (2001). The structure of the beta-catenin/E-cadherin complex and the molecular basis of diverse ligand recognition by beta-catenin. Cel/105: 391-402.

HUBER, O., KORN, R., MCLAUGHLIN, J., OHSUGI, M., HERRMANN, B.G. and KEMLER, R. (1996). Nuclear localization of beta-catenin by interaction with transcription factor LEF-1. Mech Dev 59: 3-10.

HULSKEN, J., BIRCHMEIER, W. and BEHRENS, J. (1994). E-cadherin and APC compete for the interaction with beta-catenin and the cytoskeleton. $J$ Cel/ Biol 127: 2061-2069.

IKEDA, S., KISHIDA, S., YAMAMOTO, H., MURAI, H., KOYAMA, S. and KIKUCHI, A. (1998). Axin, a negative regulator of the Wnt signaling pathway, forms a complex with GSK-3beta and beta-catenin and promotes GSK-3beta-dependent phosphorylation of beta-catenin. EMBO J17: 1371-1384.

INOMATA, M., OCHIAI, A., AKIMOTO, S., KITANO, S. and HIROHASHI, S. (1996). Alteration of beta-catenin expression in colonic epithelial cells of familial adenomatous polyposis patients. Cancer Res 56: 2213-2217.

JHO, E.H., ZHANG, T., DOMON, C., JOO, C.K., FREUND, J.N. and COSTANTINI, $\mathrm{F}$. (2002). Wnt/beta-catenin/Tcf signaling induces the transcription of Axin2, a negative regulator of the signaling pathway. Mol Cel/ Biol22: 1172-1183.

JIMBO, T., KAWASAKI, Y., KOYAMA, R., SATO, R., TAKADA, S., HARAGUCHI, K. and AKIYAMA, T. (2002). Identification of a link between the tumour suppressor APC and the kinesin superfamily. Nat Cel/ Bio/4: 323-327.

KAPLAN, D.D., MEIGS, T.E., KELLY, P. and CASEY, P.J. (2004). Identification of a role for beta -catenin in the establishment of a bipolar mitotic spindle. $J$ Biol Chem.

KAPLAN, K.B., BURDS, A.A., SWEDLOW, J.R., BEKIR, S.S., SORGER, P.K. and NATHKE, I.S. (2001). A role for the Adenomatous Polyposis Coli protein in chromosome segregation. Nat Cell Bio/3: 429-432.

KAWASAKI, Y., SATO, R., AKIYAMA, T., SENDA, T., ISHIDATE, T., KOYAMA, R., MORISHITA, T., IWAYAMA, Y. and HIGUCHI, O. (2003). Mutated APC and Asef are involved in the migration of colorectal tumour cells. Nat Cel/ Bio/5:211215.

KAWASAKI, Y., SENDA, T., ISHIDATE, T., KOYAMA, R., MORISHITA, T., IWAYAMA, Y., HIGUCHI, O. and AKIYAMA, T. (2000). Asef, a link between the tumor suppressor APC and G-protein signaling. Science 289: 1194-1197.

KIM, P.J., PLESCIA, J., CLEVERS, H., FEARON, E.R. and ALTIERI, D.C. (2003). Survivin and molecular pathogenesis of colorectal cancer. Lancet 362: 205209.

KINZLER, K.W. and VOGELSTEIN, B. (1996). Lessons from hereditary colorectal cancer. Cel/87: 159-170.

KISHIDA, S., YAMAMOTO, H., IKEDA, S., KISHIDA, M., SAKAMOTO, I., KOYAMA, S. and KIKUCHI, A. (1998). Axin, a negative regulator of the wnt signaling pathway, directly interacts with adenomatous polyposis coli and regulates the stabilization of beta-catenin. J Biol Chem 273: 10823-10826. 
KITAEVA, M.N., GROGAN, L., WILLIAMS, J.P., DIMOND, E., NAKAHARA, K., HAUSNER, P., DENOBILE, J.W., SOBALLE, P.W. and KIRSCH, I.R. (1997) Mutations in beta-catenin are uncommon in colorectal cancer occurring in occasional replication error-positive tumors. Cancer Res 57: 4478-4481.

KITAGAWA, M., HATAKEYAMA, S., SHIRANE, M., MATSUMOTO, M., ISHIDA, N., HATTORI, K., NAKAMICHI, I., KIKUCHI, A. and NAKAYAMA, K. (1999). An Fbox protein, FWD1, mediates ubiquitin-dependent proteolysis of beta-catenin. EMBO J18: 2401-2410.

KOCH, A., DENKHAUS, D., ALBRECHT, S., LEUSCHNER, I., VON SCHWEINITZ, D. and PIETSCH, T. (1999). Childhood hepatoblastomas frequently carry a mutated degradation targeting box of the beta-catenin gene. Cancer Res 59: 269-273.

$\mathrm{KOCH}$, A., WAHA, A., TONN, J.C., SORENSEN, N., BERTHOLD, F., WOLTER, M. REIFENBERGER, J., HARTMANN, W., FRIEDL, W., REIFENBERGER, G., WIESTLER, O.D. and PIETSCH, T. (2001). Somatic mutations of WNT/wingless signaling pathway components in primitive neuroectodermal tumors. Int $J$ Cancer93: 445-449.

KOESTERS, R., RIDDER, R., KOPP-SCHNEIDER, A., BETTS, D., ADAMS, V., NIGGLI, F., BRINER, J. and VON KNEBEL DOEBERITZ, M. (1999). Mutational activation of the beta-catenin proto-oncogene is a common event in the development of Wilms' tumors. Cancer Res 59: 3880-3882.

KOLLIGS, F.T., HU, G., DANG, C.V. and FEARON, E.R. (1999). Neoplastic transformation of RK3E by mutant beta-catenin requires deregulation of Tcf/Lef transcription but not activation of c-myc expression. Mol Cell Biol 19: 56965706.

KORINEK, V., BARKER, N., MORIN, P.J., VAN WICHEN, D., DE WEGER, R., KINZLER, K.W., VOGELSTEIN, B. and CLEVERS, H. (1997). Constitutive transcriptional activation by a beta-catenin-Tcf complex in APC-/- colon carcinoma. Science 275: 1784-1787.

KRAMPS, T., PETER, O., BRUNNER, E., NELLEN, D., FROESCH, B., CHATTERJEE, S., MURONE, M., ZULLIG, S. and BASLER, K. (2002). Wnt/ wingless signaling requires BCL9/legless-mediated recruitment of pygopus to the nuclear beta-catenin-TCF complex. Cel/109: 47-60.

KUHL, M. (2004). The WNT/Calcium pathway: biochemical mediators, tools and future requirements. Front Biosci9: 967-974.

KUSAFUKA, T., MIAO, J., KURODA, S., UDATSU, Y. and YONEDA, A. (2002). Codon 45 of the beta-catenin gene, a specific mutational target site of Wilms' tumor. Int J Mol Med 10: 395-399.

LEE, J.H., ABRAHAM, S.C., KIM, H.S., NAM, J.H., CHOI, C., LEE, M.C., PARK, C.S., JUHNG, S.W., RASHID, A., HAMILTON, S.R. and WU, T.T. (2002) Inverse relationship between APC gene mutation in gastric adenomas and development of adenocarcinoma. Am J Patho/161: 611-618.

LEPOURCELET, M., CHEN, Y.N., FRANCE, D.S., WANG, H., CREWS, P., PETERSEN, F., BRUSEO, C., WOOD, A.W. and SHIVDASANI, R.A. (2004). Small-molecule antagonists of the oncogenic Tcf/beta-catenin protein complex. Cancer Cel/5: 91-102.

LEUNG, J.Y., KOLLIGS, F.T., WU, R., ZHAI, Y., KUICK, R., HANASH, S., CHO, K.R. and FEARON, E.R. (2002). Activation of AXIN2 expression by betacatenin-T cell factor. A feedback repressor pathway regulating Wnt signaling. $J$ Biol Chem 277: 21657-21665

LIU, C., LI, Y., SEMENOV, M., HAN, C., BAEG, G.H., TAN, Y., ZHANG, Z., LIN, X. and $\mathrm{HE}, \mathrm{X}$. (2002). Control of beta-catenin phosphorylation/degradation by a dual-kinase mechanism. Cel/108: 837-847.

LIU, W., DONG, X., MAI, M., SEELAN, R.S., TANIGUCHI, K., KRISHNADATH, K.K., HALLING, K.C., CUNNINGHAM, J.M., BOARDMAN, L.A., QIAN, C., CHRISTENSEN, E., SCHMIDT, S.S., ROCHE, P.C., SMITH, D.I. and THIBODEAU, S.N. (2000). Mutations in AXIN2 cause colorectal cancer with defective mismatch repair by activating beta-catenin/TCF signalling. Nat Genet 26: $146-147$.

LUSTIG, B. and BEHRENS, J. (2003). The Wnt signaling pathway and its role in tumor development. J Cancer Res Clin Oncol129: 199-221.

LUSTIG, B., JERCHOW, B., SACHS, M., WEILER, S., PIETSCH, T., KARSTEN, U., VAN DE WETERING, M., CLEVERS, H., SCHLAG, P.M., BIRCHMEIER, W. and BEHRENS, J. (2002). Negative feedback loop of Wnt signaling through upregulation of conductin/axin2 in colorectal and liver tumors. Mo/ Cel/ Biol22: 1184-1193
MAITI, S., ALAM, R., AMOS, C.I. and HUFF, V. (2000). Frequent association of beta-catenin and WT1 mutations in Wilms tumors. Cancer Res 60: 6288-6292.

MAO, B., WU, W., DAVIDSON, G., MARHOLD, J., LI, M., MECHLER, B.M., DELIUS, H., HOPPE, D., STANNEK, P., WALTER, C., GLINKA, A. and NIEHRS, C. (2002). Kremen proteins are Dickkopf receptors that regulate Wnt/ beta-catenin signalling. Nature 417: 664-667.

MAO, B., WU, W., LI, Y., HOPPE, D., STANNEK, P., GLINKA, A. and NIEHRS, C. (2001a). LDL-receptor-related protein 6 is a receptor for Dickkopf proteins. Nature 411: 321-325

MAO, J., WANG, J., LIU, B., PAN, W., FARR, G.H., 3RD, FLYNN, C., YUAN, H., TAKADA, S., KIMELMAN, D., LI, L. and WU, D. (2001b). Low-density lipoprotein receptor-related protein- 5 binds to Axin and regulates the canonical Wnt signaling pathway. Mo/ Cel/7: 801-809.

MARCHENKO, G.N., MARCHENKO, N.D., LENG, J. and STRONGIN, A.Y. (2002). Promoter characterization of the novel human matrix metalloproteinase-26 gene: regulation by the T-cell factor- 4 implies specific expression of the gene in cancer cells of epithelial origin. Biochem J363: 253-262.

MILLER, J.R. (2002). The Wnts. Genome Bio/3: REVIEWS3001.

MIRABELLI-PRIMDAHL, L., GRYFE, R., KIM, H., MILLAR, A., LUCERI, C., DALE, D., HOLOWATY, E., BAPAT, B., GALLINGER, S. and REDSTON, M. (1999). Beta-catenin mutations are specific for colorectal carcinomas with microsatellite instability but occur in endometrial carcinomas irrespective of mutator pathway. Cancer Res 59: 3346-3351.

MIYAKI, M., IIJIMA, T., KIMURA, J., YASUNO, M., MORI, T., HAYASHI, Y., KOIKE, M., SHITARA, N., IWAMA, T. and KUROKI, T. (1999). Frequent mutation of beta-catenin and APC genes in primary colorectal tumors from patients with hereditary nonpolyposis colorectal cancer. Cancer Res 59: 4506-4509.

MOGENSEN, M.M., TUCKER, J.B., MACKIE, J.B., PRESCOTT, A.R. and NATHKE, I.S. (2002). The adenomatous polyposis coli protein unambiguously localizes to microtubule plus ends and is involved in establishing parallel arrays of microtubule bundles in highly polarized epithelial cells. J Cel/ Bio/157: 1041-1048.

MOLENAAR, M., VAN DE WETERING, M., OOSTERWEGEL, M., PETERSONMADURO, J., GODSAVE, S., KORINEK, V., ROOSE, J., DESTREE, O. and CLEVERS, H. (1996). XTcf-3 transcription factor mediates beta-catenin-induced axis formation in Xenopus embryos. Cel/86: 391-399.

MORENO-BUENO, G., HARDISSON, D., SANCHEZ, C., SARRIO, D., CASSIA, R., GARCIA-ROSTAN, G., PRAT, J., GUO, M., HERMAN, J.G., MATIAS-GUIU, X. ESTELLER, M. and PALACIOS, J. (2002). Abnormalities of the APC/betacatenin pathway in endometrial cancer. Oncogene 21: 7981-7990.

MORIN, P.J., SPARKS, A.B., KORINEK, V., BARKER, N., CLEVERS, H., VOGELSTEIN, B. and KINZLER, K.W. (1997). Activation of beta-catenin-Tcf signaling in colon cancer by mutations in beta-catenin or APC. Science 275: 1787-1790.

MULHOLLAND, D.J., CHENG, H., REID, K., RENNIE, P.S. and NELSON, C.C. (2002). The androgen receptor can promote beta-catenin nuclear translocation independently of adenomatous polyposis coli. J Biol Chem 277: 17933-17943.

NATHKE, I.S., ADAMS, C.L., POLAKIS, P., SELLIN, J.H. and NELSON, W.J. (1996). The adenomatous polyposis coli tumor suppressor protein localizes to plasma membrane sites involved in active cell migration. J Cell Bio/134: 165-179.

OLMEDA, D., CASTEL, S., VILARO, S. and CANO, A. (2003). Beta-catenin regulation during the cell cycle: implications in G2/M and apoptosis. $\mathrm{Mo} / \mathrm{BiO} / \mathrm{Ce} / /$ 14: $2844-2860$

ORFORD, K., ORFORD, C.C. and BYERS, S.W. (1999). Exogenous expression of beta-catenin regulates contact inhibition, anchorage-independent growth, anoikis, and radiation-induced cell cycle arrest. J Cel/ Bio/146: 855-868.

OUGOLKOV, A.V., YAMASHITA, K., MAI, M. and MINAMOTO, T. (2002). Oncogenic beta-catenin and MMP-7 (matrilysin) cosegregate in late-stage clinical colon cancer. Gastroenterology 122: 60-71.

PARK, W.S., OH, R.R., PARK, J.Y., KIM, P.J., SHIN, M.S., LEE, J.H., KIM, H.S., LEE, S.H., KIM, S.Y., PARK, Y.G., AN, W.G., JANG, J.J., YOO, N.J. and LEE, J.Y. (2001). Nuclear localization of beta-catenin is an important prognostic factor in hepatoblastoma. J Patho/193: 483-490.

PARK, W.S., OH, R.R., PARK, J.Y., LEE, S.H., SHIN, M.S., KIM, Y.S., KIM, S.Y., LEE, H.K., KIM, P.J., OH, S.T., YOO, N.J. and LEE, J.Y. (1999). Frequent somatic mutations of the beta-catenin gene in intestinal-type gastric cancer. Cancer Res 59: 4257-4260. 
PEIFER, M., BERG, S. and REYNOLDS, A.B. (1994). A repeating amino acid motif shared by proteins with diverse cellular roles. Cel/76: 789-791.

POLAKIS, P. (2000). Wnt signaling and cancer. Genes Dev14: 1837-1851.

RIJSEWIJK, F., SCHUERMANN, M., WAGENAAR, E., PARREN, P., WEIGEL, D. and NUSSE, R. (1987a). The Drosophila homolog of the mouse mammary oncogene int- 1 is identical to the segment polarity gene wingless. Cel/50: 649 657.

RIJSEWIJK, F., VAN DEEMTER, L., WAGENAAR, E., SONNENBERG, A. and NUSSE, R. (1987b). Transfection of the int-1 mammary oncogene in cuboidal RAC mammary cell line results in morphological transformation and tumorigenicity. EMBO J6: 127-131.

RIMM, D.L., CACA, K., HU, G., HARRISON, F.B. and FEARON, E.R. (1999). Frequent nuclear/cytoplasmic localization of beta-catenin without exon 3 mutations in malignant melanoma. Am J Patho/154: 325-329.

ROOSE, J., HULS, G., VAN BEEST, M., MOERER, P., VAN DER HORN, K., GOLDSCHMEDING, R., LOGTENBERG, T. and CLEVERS, H. (1999). Synergy between tumor suppressor APC and the beta-catenin-Tcf4 target Tcf1. Science 285: 1923-1926.

ROOSE, J., MOLENAAR, M., PETERSON, J., HURENKAMP, J., BRANTJES, H., MOERER, P., VAN DE WETERING, M., DESTREE, O. and CLEVERS, H. (1998) The Xenopus Wnt effector XTcf-3 interacts with Groucho-related transcriptional repressors. Nature 395: 608-612.

ROSIN-ARBESFELD, R., CLIFFE, A., BRABLETZ, T. and BIENZ, M. (2003). Nuclear export of the APC tumour suppressor controls beta-catenin function in transcription EMBO J22: 1101-1113.

ROUSSET, R., MACK, J.A., WHARTON, K.A., JR., AXELROD, J.D., CADIGAN, K.M., FISH, M.P., NUSSE, R. and SCOTT, M.P. (2001). Naked cuticle targets dishevelled to antagonize Wnt signal transduction. Genes Dev15: 658-671.

RUBINFELD, B., ALBERT, I., PORFIRI, E., FIOL, C., MUNEMITSU, S. and POLAKIS, P. (1996). Binding of GSK3beta to the APC-beta-catenin complex and regulation of complex assembly. Science 272: 1023-1026.

RUCKERT, S., HIENDLMEYER, E., BRUECKL, W.M., OSWALD, U., BEYSER, K. DIETMAIER, W., HAYNL, A., KOCH, C., RUSCHOFF, J., BRABLETZ, T. KIRCHNER, T. and JUNG, A. (2002). T-cell factor-4 frameshift mutations occur frequently in human microsatellite instability-high colorectal carcinomas but do not contribute to carcinogenesis. Cancer Res 62: 3009-3013.

SATOH, S., DAIGO, Y., FURUKAWA, Y., KATO, T., MIWA, N., NISHIWAKI, T., KAWASOE, T., ISHIGURO, H., FUJITA, M., TOKINO, T., SASAKI, Y., IMAOKA, S. MURATA, M., SHIMANO, T., YAMAOKA, Y. and NAKAMURA, Y. (2000). AXIN1 mutations in hepatocellular carcinomas, and growth suppression in cancer cells by virus-mediated transfer of AXIN1. Nat Genet 24: 245-250.

SCHWARTZ, D.R., WU, R., KARDIA, S.L., LEVIN, A.M., HUANG, C.C., SHEDDEN, K.A., KUICK, R., MISEK, D.E., HANASH, S.M., TAYLOR, J.M., REED, H., HENDRIX N., ZHAI, Y., FEARON, E.R. and CHO, K.R. (2003). Novel candidate targets of betacatenin/T-cell factor signaling identified by gene expression profiling of ovarian endometrioid adenocarcinomas. Cancer Res 63: 2913-2922.

SCHWARZ-ROMOND, T., ASBRAND, C., BAKKERS, J., KUHL, M., SCHAEFFER, H.J., HUELSKEN, J., BEHRENS, J., HAMMERSCHMIDT, M. and BIRCHMEIER, W. (2002). The ankyrin repeat protein Diversin recruits Casein kinase lepsilon to the beta-catenin degradation complex and acts in both canonical Wnt and Wnt/JNK signaling. Genes Dev 16: 2073-2084.

SEELING, J.M., MILLER, J.R., GIL, R., MOON, R.T., WHITE, R. and VIRSHUP, D.M. (1999). Regulation of beta-catenin signaling by the B56 subunit of protein phosphatase 2A. Science 283: 2089-2091.

SEIDENSTICKER, M.J. and BEHRENS, J. (2000). Biochemical interactions in the wnt pathway. Biochim Biophys Acta 1495: 168-182.

SHIMIZU, H., JULIUS, M.A., GIARRE, M., ZHENG, Z., BROWN, A.M. and KITAJEWSKI, J. (1997). Transformation by Wnt family proteins correlates with regulation of betacatenin. Cell Growth Differ8: 1349-1358.

SHIMOKAWA, T., FURUKAWA, Y., SAKAI, M., LI, M., MIWA, N., LIN, Y.M. and NAKAMURA, Y. (2003). Involvement of the FGF18 gene in colorectal carcinogenesis, as a novel downstream target of the beta-catenin/T-cell factor complex. Cancer Res 63: 6116-6120.

SHTUTMAN, M., ZHURINSKY, J., SIMCHA, I., ALBANESE, C., D'AMICO, M., PESTELL, R. and BEN-ZE'EV, A. (1999). The cyclin D1 gene is a target of the beta-catenin/ LEF-1 pathway. Proc Nat/ Acad Sci USA 96: 5522-5527.
SPARKS, A.B., MORIN, P.J., VOGELSTEIN, B. and KINZLER, K.W. (1998) Mutational analysis of the APC/beta-catenin/Tcf pathway in colorectal cancer. Cancer Res 58: 1130-1134.

SPINK, K.E., POLAKIS, P. and WEIS, W.I. (2000). Structural basis of the Axinadenomatous polyposis coli interaction. EMBO J19: 2270-2279.

STOCKINGER, A., EGER, A., WOLF, J., BEUG, H. and FOISNER, R. (2001). Ecadherin regulates cell growth by modulating proliferation-dependent betacatenin transcriptional activity. J Cel/ Bio/154: 1185-1196.

SUN, T.Q., LU, B., FENG, J.J., REINHARD, C., JAN, Y.N., FANTL, W.J. and WILLIAMS, L.T. (2001). PAR-1 is a Dishevelled-associated kinase and a positive regulator of Wnt signalling. Nat Cel/ Bio/3: 628-636.

TAGO, K., NAKAMURA, T., NISHITA, M., HYODO, J., NAGAI, S., MURATA, Y., ADACHI, S., OHWADA, S., MORISHITA, Y., SHIBUYA, H. and AKIYAMA, T. (2000). Inhibition of Wnt signaling by ICAT, a novel beta-catenin-interacting protein. Genes Dev 14: 1741-1749.

TAKEMARU, K., YAMAGUCHI, S., LEE, Y.S., ZHANG, Y., CARTHEW, R.W. and MOON, R.T. (2003). Chibby, a nuclear beta-catenin-associated antagonist of the Wnt/Wingless pathway. Nature 422: 905-909.

TAMAI, K., SEMENOV, M., KATO, Y., SPOKONY, R., LIU, C., KATSUYAMA, Y., HESS, F., SAINT-JEANNET, J.P. and HE, X. (2000). LDL-receptor-related proteins in Wnt signal transduction. Nature 407: 530-535.

TANIGUCHI, K., ROBERTS, L.R., ADERCA, I.N., DONG, X., QIAN, C., MURPHY, L.M., NAGORNEY, D.M., BURGART, L.J., ROCHE, P.C., SMITH, D.I., ROSS, J.A. and LIU, W. (2002). Mutational spectrum of beta-catenin, AXIN1, and AXIN2 in hepatocellular carcinomas and hepatoblastomas. Oncogene 21: 4863-4871.

TETSU, O. and MCCORMICK, F. (1999). Beta-catenin regulates expression of cyclin D1 in colon carcinoma cells. Nature 398: $422-426$.

THOMPSON, B., TOWNSLEY, F., ROSIN-ARBESFELD, R., MUSISI, H. and BIENZ, M. (2002). A new nuclear component of the Wnt signalling pathway. Nat Cell Bio/4: 367-373.

TRUICA, C.I., BYERS, S. and GELMANN, E.P. (2000). Beta-catenin affects androgen receptor transcriptional activity and ligand specificity. Cancer Res60: 4709-4713.

VAN DE WETERING, M., CAVALLO, R., DOOIJES, D., VAN BEEST, M., VAN ES, J., LOUREIRO, J., YPMA, A., HURSH, D., JONES, T., BEJSOVEC, A., PEIFER, M., MORTIN, M. and CLEVERS, H. (1997). Armadillo coactivates transcription driven by the product of the Drosophila segment polarity gene dTCF. Cel/88: 789-799.

VAN DE WETERING, M., OVING, I., MUNCAN, V., PON FONG, M.T., BRANTJES, H., VAN LEENEN, D., HOLSTEGE, F.C., BRUMMELKAMP, T.R., AGAMI, R. and CLEVERS, H. (2003). Specific inhibition of gene expression using a stably integrated, inducible small-interfering-RNA vector. EMBO Rep 4: 609-615.

VAN DE WETERING, M., SANCHO, E., VERWEIJ, C., DE LAU, W., OVING, I., HURLSTONE, A., VAN DER HORN, K., BATLLE, E., COUDREUSE, D., HARAMIS, A.P., TJON-PON-FONG, M., MOERER, P., VAN DEN BORN, M., SOETE, G., PALS, S., EILERS, M., MEDEMA, R. and CLEVERS, H. (2002). The beta-catenin/TCF-4 complex imposes a crypt progenitor phenotype on colorectal cancer cells. Cel/111: 241-250.

VEEMAN, M.T., AXELROD, J.D. and MOON, R.T. (2003). A second canon. Functions and mechanisms of beta-catenin-independent Wnt signaling. Dev Cel/5: 367-377.

VOELLER, H.J., TRUICA, C.I. and GELMANN, E.P. (1998). Beta-catenin mutations in human prostate cancer. Cancer Res 58: 2520-2523.

VON KRIES, J.P., WINBECK, G., ASBRAND, C., SCHWARZ-ROMOND, T., SOCHNIKOVA, N., DELL'ORO, A., BEHRENS, J. and BIRCHMEIER, W. (2000). Hot spots in beta-catenin for interactions with LEF-1, conductin and APC. Nat Struct Bio/7: 800-807.

WAKEFIELD, J.G., STEPHENS, D.J. and TAVARE, J.M. (2003). A role for glycogen synthase kinase-3 in mitotic spindle dynamics and chromosome alignment. $J$ Cell Sci116: 637-646.

WEHRLI, M., DOUGAN, S.T., CALDWELL, K., O'KEEFE, L., SCHWARTZ, S., VAIZEL-OHAYON, D., SCHEJTER, E., TOMLINSON, A. and DINARDO, S. (2000). arrow encodes an LDL-receptor-related protein essential for Wingless signalling. Nature 407: 527-530. 
WHARTON, K.A., JR. (2003). Runnin' with the Dvl: proteins that associate with Dsh/ Dvl and their significance to Wnt signal transduction. Dev Bio/253: 1-17.

WIDLUND, H.R., HORSTMANN, M.A., PRICE, E.R., CUI, J., LESSNICK, S.L., WU, M., HE, X. and FISHER, D.E. (2002). Beta-catenin-induced melanoma growth requires the downstream target Microphthalmia-associated transcription factor. $J$ Cell Biol158: 1079-1087.

WIELENGA, V.J., SMITS, R., KORINEK, V., SMIT, L., KIELMAN, M., FODDE, R., CLEVERS, H. and PALS, S.T. (1999). Expression of CD44 in Apc and Tcf mutant mice implies regulation by the WNT pathway. Am J Patho/154: 515-523.

WINSTON, J.T., STRACK, P., BEER-ROMERO, P., CHU, C.Y., ELLEDGE, S.J. and HARPER, J.W. (1999). The SCFbeta-TRCP-ubiquitin ligase complex associates specifically with phosphorylated destruction motifs in IkappaBalpha and betacatenin and stimulates IkappaBalpha ubiquitination in vitro. Genes Dev 13: 270283.

WU, R., ZHAI, Y., FEARON, E.R. and CHO, K.R. (2001). Diverse mechanisms of betacatenin deregulation in ovarian endometrioid adenocarcinomas. Cancer Res 61: 8247-8255.

YAMAMOTO, H., KISHIDA, S., KISHIDA, M., IKEDA, S., TAKADA, S. and KIKUCHI, A. (1999). Phosphorylation of axin, a Wnt signal negative regulator, by glycogen synthase kinase-3beta regulates its stability. J Biol Chem 274: 10681-10684.

YANG, F., LI, X., SHARMA, M., SASAKI, C.Y., LONGO, D.L., LIM, B. and SUN, Z. (2002). Linking beta-catenin to androgen-signaling pathway. J Biol Chem 277: $11336-11344$.
YOST, C., FARR, G.H., 3RD, PIERCE, S.B., FERKEY, D.M., CHEN, M.M. and KIMELMAN, D. (1998). GBP, an inhibitor of GSK-3, is implicated in Xenopus development and oncogenesis. Cel/93: 1031-1041.

YOUNG, C.S., KITAMURA, M., HARDY, S. and KITAJEWSKI, J. (1998). Wnt-1 induces growth, cytosolic beta-catenin, and Tcf/Lef transcriptional activation in Rat-1 fibroblasts. Mol Cel/ Bio/18: 2474-2485.

ZENG, L., FAGOTTO, F., ZHANG, T., HSU, W., VASICEK, T.J., PERRY, W.L., 3RD, LEE, J.J., TILGHMAN, S.M., GUMBINER, B.M. and COSTANTINI, F. (1997). The mouse Fused locus encodes Axin, an inhibitor of the Wnt signaling pathway that regulates embryonic axis formation. Cel/90: 181-192.

ZHANG, T., OTEVREL, T., GAO, Z., EHRLICH, S.M., FIELDS, J.Z. and BOMAN, B.M (2001a). Evidence that APC regulates survivin expression: a possible mechanism contributing to the stem cell origin of colon cancer. Cancer Res 61: 8664-8667.

ZHANG, X., GASPARD, J.P. and CHUNG, D.C. (2001b). Regulation of vascular endothelial growth factor by the Wnt and K-ras pathways in colonic neoplasia. Cancer Res 61: 6050-6054.

ZUMBRUNN, J., KINOSHITA, K., HYMAN, A.A. and NATHKE, I.S. (2001). Binding of the adenomatous polyposis coli protein to microtubules increases microtubule stability and is regulated by GSK3 beta phosphorylation. Curr Bio/11: 44-49.

ZURAWEL, R.H., CHIAPPA, S.A., ALLEN, C. and RAFFEL, C. (1998). Sporadic medulloblastomas contain oncogenic beta-catenin mutations. Cancer Res 58: 896-899. 